MISES: Revista Interdisciplinar de Filosofia, Direito e Economia

ISSN 2318-0811

Volume III, Número 2 (Edição 6) Julho-Dezembro 2015: 479-500

\title{
Reflexões Sobre a Formação e a Distribição das Riquezas - Parte II $^{*}$
}

\author{
Anne Robert Jacques Turgot ${ }^{* *}$
}

\begin{abstract}
Resumo: O autor defende que a geração de riquezas é impossível na presença de políticas distributivas, utilizando o fator terra como tema principal de sua análise. Defende o livre comércio, os direitos de propriedade e mostra como as trocas voluntárias e a divisão do trabalho, com a consequente geração de riqueza, surgem exatamente da desigualdade na distribuição da terra.

Palavras-Chave: Riqueza, Comércio, Terras, Capital, Divisão do trabalho.
\end{abstract}

\section{Reflections On the Formation and Distribution of Wealth - Part II}

\begin{abstract}
The author sustains that it is impossible to create wealth in the presence of redistributive policies, using the land factor as the main theme of his analysis. He defends free trade and property rights, and shows how voluntary exchanges and the division of labor, with the consequent generation of wealth, arise exactly from the unequal distribution of land.
\end{abstract}

Keywords: Wealth. Trade. Lands. Capital. Division of labor.

Classificação JEL: B31, P14, P48.

\footnotetext{
* O texto foi publicado originalmente em francês em 1766 com o título Réflexions sur la formation et la distribution des richesses. A presente tradução foi feita a partir do arquivo em PDF da edição original, disponibilizado on line pela Bibliothèque Nationale de France. Optou-se por publicar o texto em duas partes. A primeira parte foi publicada na edição anterior de MISES: Revista Interdisciplinar de Filosofia, Direito e Economia.

Traduzido do original em francês para o português por Carlos Nougué e Daniel Aveline.
}

** Anne Marie Jacques Turgot, o Barão de de l'Aulne, nasceu em 10 de maio de 1727, em Paris. Estudou Teologia na Universidade de Sorbonne. Manteve contato com os economistas fisiocratas e com os filósofos iluministas franceses, bem como com diversos pensadores britânicos. Colaborou com diversos verbetes para e escreveu várias obras, dentre as quais se destacam os livros Lettres sur la tolérance civile (1754), Réflexions sur la formation et la distribution des richesses (1766) e Lettres sur la liberté de commerce des grains (1770). Trabalhou como conselheiro do Parlamento de Paris, como intendente da cidade de Limonges e, entre 1774 e 1776, como ministro-geral das Finanças. Tanto no plano das ideias como na atuação nos cargos públicos, sempre advogou o livre mercado, opondo-se ao intervencionismo estatal. Faleceu em Paris, no dia 18 de março de 1781. 
$\mathrm{L}$

Riquezas mobiliárias, acumulação de dinheiro.

O tipo de posse resultante da acumulação dos produtos anuais não consumidos conhece-se pelo nome de riquezas mobiliárias. Os móveis, as casas, a baixela, as mercadorias armazenadas, as ferramentas de cada ofício e o gado pertencem a este tipo de riquezas. É evidente que as pessoas se esforçaram grandemente por obter o mais que pudessem dessas riquezas antes de conhecer o dinheiro; mas não é menos sensível que, assim que foi conhecido e reconhecido como o mais inalterável de todos os objetos do comércio, e o mais fácil de conservar sem dificuldades, ele deve ter sido principalmente procurado por quem quer que quisesse acumular. Não foram somente os proprietários das terras os que amealharam assim seu excedente. Ainda que os lucros da indústria não sejam, como as rendas da terra, uma benesse da natureza, e que o homem industrioso não retire de seu trabalho senão o preço que lhe dá aquele que paga seu soldo, ainda que este último economize o mais que possa desse salário, e que a concorrência obrigue o homem industrioso a contentar-se com um preço menor do que gostaria, é certo, no entanto, que tal concorrência não foi jamais numerosa o bastante, animada o bastante, em todos os tipos de trabalho, para que um homem mais hábil, mais ativo e sobretudo mais econômico que os outros em seu consumo pessoal não tenha podido, a qualquer tempo, ganhar um pouco mais que o preciso para fazê-lo subsistir a ele e à sua família, e guardar o excedente para com ele formar um pequeno pecúlio.

\section{LI}

As riquezas mobiliárias são pré-requisito indispensável a todos os trabalhos lucrativos.

É de fato necessário que, em cada ofício, os trabalhadores, ou os empreendedores que os fazem trabalhar, tenham certo fundo de ri- quezas mobiliárias acumuladas previamente. Somos aqui novamente obrigados a voltar sobre nossos passos para lembrar diversas coisas que, inicialmente, foram apenas indicadas de passagem quando falamos da divisão das diferentes profissões e dos diferentes meios pelos quais os proprietários podem explorar seus fundos, porque assim poderíamos melhor explicá-las sem interromper o segmento das ideias.

\section{LII}

Necessidade de investimentos para a cultura.

Todos os tipos de trabalhos da cultura, da indústria, do comércio exigem investimentos. Se se lavrasse a terra com as mãos, seria preciso semear antes de colher: seria preciso viver até a colheita. Quanto mais a cultura se aperfeiçoa e se anima, tanto maiores são os investimentos. São necessários o gado, as ferramentas aratórias, construções para conter o gado, para cercar a colheita; é preciso pagar e fazer subsistir até à colheita um número de pessoas proporcional à extensão da exploração. Não é senão por grandes investimentos que se obtêm ricos produtos e que as terras dão bastante retorno. Em qualquer ofício, é preciso antes que o trabalhador tenha as ferramentas, que tenha quantidade suficiente dos materiais que são o objeto de seu trabalho; é preciso que ele subsista enquanto espera a venda de suas obras.

\section{LIII \\ Primeiros investimentos dados pela terra ainda inculta.}

É sempre a terra a primeira e única fonte de toda a riqueza: é ela que, pela cultura, produz toda a renda; foi ela também a que deu o primeiro fundo de investimentos anteriores a qualquer cultura. O primeiro cultivador tomou os grãos que semeou das plantas que a terra havia produzido por si mesma; espe- 
rando a colheita, viveu de caça, de pesca, de frutas selvagens: suas ferramentas foram os galhos de árvores arrancadas nas florestas, talhados com pedras cortantes, afiadas contra outras pedras; tomou ele mesmo no caminho ou fez cair em armadilhas os animais errantes dos bosques, subjugou-os, domou-os: serviu-se deles inicialmente para sua alimentação, e depois para ajudá-lo em seu trabalho. Esse primeiro fundo cresceu pouco a pouco; o gado sobretudo foi, de todas as riquezas mobiliárias, a mais procurada nesses primeiros tempos, e a que foi a mais fácil acumular: os animais perecem, mas reproduzem-se, e a riqueza é de alguma forma imperecível; esse fundo mesmo aumenta pela via única da sucessão, e dá um produto anual, seja em laticínios, seja em lãs, seja em couros e outros materiais que, com a madeira apanhada nas florestas, foram o primeiro fundo das obras da indústria.

\section{LIV \\ Gado, riqueza mobiliária anterior até à cultura das terras.}

Em um tempo em que havia ainda grande quantidade de terras incultas e que não pertenciam a ninguém, pôde alguém ter gado sem ser proprietário de terras. É mesmo provável que os homens tenham quase por todos os lugares começado a reunir rebanhos e a viver de seu produto antes de entregar-se ao trabalho mais penoso da cultura. Parece que as nações que mais antigamente cultivaram a terra são as que encontraram em seu país espécies de animais mais aptas a domar-se, e que com isso foram conduzidas da vida errante e agitada dos povos que vivem da caça e da pesca à vida mais tranquila dos povos pastores. A vida pastoral faz permanecer mais tempo em um mesmo lugar; oferece mais ócio; mais ocasiões para estudar a diferença dos terrenos, para observar a marcha da natureza na produção de plantas que servem à alimentação do gado. Talvez seja por essa razão que as nações asiáticas cultivaram a terra primeiro, e que os povos da América tenham ficado por tanto tempo em estado selvagem.

\section{$\mathrm{LV}$}

Outro tipo de riqueza mobiliária e de investimentos da cultura: os escravos.

Os escravos foram outro tipo de riqueza mobiliária, obtido inicialmente pela violência e em seguida por via do comércio e da troca. Os que tinham muitos deles usavam-nos não somente na cultura das terras, mas ainda em diferentes trabalhos da indústria. A facilidade, quase sem limite, de acumular estas duas espécies de riquezas e de fazer uso delas mesmo independentemente das terras fez que se pudessem avaliar as terras em si mesmas e se pudesse comparar seu valor ao das riquezas mobiliárias.

\section{LVI \\ As riquezas mobiliárias têm valor de troca pela terra em si.}

Um homem que tivesse grande quantidade de terras sem gado nem escravos teria certamente feito vantajoso negócio cedendo uma parte de suas terras a um homem que lhe desse em troca gado e escravos para cultivar o restante. Foi principalmente assim que os fundos de terras entraram no comércio e alcançaram valor comparável ao de todos os outros produtos. Se quatro alqueires de trigo, produto líquido de um acre de terra, valiam seis ovelhas, o acre em si que os produzia poderia ter sido negociado por certo valor, na verdade maior, mas mesmo assim fácil de determinar, assim como o preço de todas as outras mercadorias; isto é, inicialmente pelo debate entre os dois contratantes; e em seguida conforme ao preço corrente estabelecido pela concorrência dos que querer trocar terras por gado, e dos que querem dar gado para ter terras. É conforme a esse preço corrente que se avaliam as terras quando um devedor, procurado por seu credor, é obrigado a ceder-lhe seu fundo. 


\section{LVII}

Avaliação das terras pela proporção da renda com a soma das riquezas mobiliárias, ou pelo valor por que são negociadas: esta proporção é o que chamamos denier ${ }^{1}$ do preço das terras.

É evidente que, se uma terra que produz renda equivalente a seis ovelhas pode sempre ser vendida por certo valor exprimível em um número de ovelhas equivalente àquele valor, este terá proporção relativa a seis, e contê-lo-á certo número de vezes. O preço de um fundo será, portanto, apenas certo número de vezes sua renda; vinte vezes se o preço é de cento $e$ vinte ovelhas; trinta vezes se de cento e oitenta ovelhas. O preço corrente das terras rege-se, assim, pela proporção entre o valor do fundo e o valor da renda, e o número de vezes que o preço do fundo contém a renda chama-se denier das terras. Estas são vendidas pelo vigésimo denier, pelo trigésimo denier, pelo quadragésimo, etc., segundo se pague para ter vinte, trinta ou quarenta vezes sua renda. É evidente, ain$\mathrm{da}$, que este preço, ou denier, deve variar conforme haja mais ou menos pessoas querendo vender ou comprar terras, assim como o preço de todas as outras mercadorias varia em razão das diferentes proporções entre oferta e demanda.

\section{LVIII}

Todo e qualquer capital em dinheiro, ou toda e qualquer soma de qualquer valor, é equivalente a uma terra que produza renda igual a uma porção determinada de tal soma. Primeiro emprego dos capitais. Compra de um fundo de terras.

Transportemo-nos agora à época imediatamente posterior à introdução do dinhei-

\footnotetext{
1 Do latim denarius, aqui significa certa unidade monetária de medida, e mais adiante significará interesse sobre uma soma de dinheiro, sobre um capital. Assim, um capital posto sob denier 20 terá interesse equivalente à sua vigésima parte (5\%). [N. dos T.]
}

ro: a facilidade de acumulá-lo logo suscitou a mais cobiçada das riquezas mobiliárias, e forneceu os meios de aumentá-las incessantemente em quantidade pela simples via da economia. Quem quer que fosse, seja pela renda de sua terra, seja pelo soldo de seu trabalho e de sua indústria, agora recebia todos os anos mais do que tinha necessidade de gastar, e podia guardar esse excedente e acumulá-lo: tais valores acumulados são o que chamamos capital. O avaro pusilânime que amealha dinheiro apenas para acalmar sua imaginação contra o medo de carecer de coisas necessárias à vida em futuro incerto guarda seu dinheiro maciçamente. Se os perigos que previu se realizassem e ele fosse obrigado, pela pobreza, a viver a cada ano de seu tesouro, ou um herdeiro pródigo o desperdiçasse pouco a pouco, tal tesouro logo se esgotaria, e o capital estaria perdido para o possuidor; este pode extrair dele uma parte bem mais vantajosa. Já que um fundo de terra com certo rendimento não é senão o equivalente de uma soma de valor igual a esse rendimento multiplicado por certo número de vezes, disso se segue que uma soma qualquer de valores é o equivalente de um fundo de terras que produza renda igual à proporção relativa desta soma: é absolutamente indiferente que tal soma de valores ou tal capital consistam em uma massa de metal ou em qualquer outra coisa, pois o dinheiro representa qualquer tipo de valor, assim como qualquer tipo de valor representa o dinheiro: o possuidor de um capital pode, portanto, empregá-lo inicialmente para comprar terras; mas possui ainda outros recursos.

\section{LIX}

Outro emprego do dinheiro no investimento de empresas de fabricação e de indústria.

Já destaquei que todos os trabalhos, sejam de cultura, sejam de indústria, precisam de investimentos. E já demonstrei que a terra, pelos frutos e pelas plantas que produz por si mesma para alimentação dos homens e do gado, e as árvores de que os homens fi- 
zeram suas primeiras ferramentas, forneceram os primeiros investimentos da cultura e até dos primeiros trabalhos manuais que cada homem pode fazer para seu uso. Por exemplo, foi a terra que forneceu a pedra, a argila, a madeira com que se construíram as primeiras casas, e antes da separação das profissões, quando o mesmo homem que cultivava a terra satisfazia suas outras necessidades pelo trabalho, não eram necessários outros investimentos: quando porém grande parte da sociedade já não teve senão seus braços para viver, foi preciso que aqueles que viviam então de salários começassem a ter algo investido, seja para obter os materiais com que trabalhavam, seja para viver esperando o pagamento de seu soldo.

\section{LX}

Desenvolvimentos acerca do uso dos investimentos de capitais em empresas de indústria, de seu retorno e do lucro que devem auferir.

Em tempos primitivos, o que dava trabalho fornecia, ele mesmo, o material e pagava dia a dia o soldo do trabalhador. O cultivador, ou o proprietário, dava, eles mesmo, à fiandeira o cânhamo que havia recolhido, e alimentava-a enquanto ela trabalhava: dava em seguida o fio ao tecelão, ao qual dava todos os dias o soldo convencionado: mas esses investimentos leves e cotidianos não podem bastar senão para os trabalhos de mão de obra bruta. Grande número de artes, e até artes ao alcance dos membros mais pobres da sociedade, exige que o mesmo material passe por multidão de mãos diferentes e sofra durante muito tempo preparações dificilíssimas e variadíssimas. Já citei a preparação dos couros com que se fazem os sapatos: quem quer que tenha visto a oficina de um curtidor sente a impossibilidade absoluta de que um homem, ou até vários homens pobres, se aprovisione de couros, de cal, de tânico, de ferramentas, etc., construa as edificações necessárias para montar um curtume e viva durante vários meses até que os couros se vendam: nesta arte e em muitas outras, não é preciso que os que trabalham tenham aprendido o ofício antes de ousar tocar o material que eles arruinariam em suas primeiras tentativas? Eis outro novo investimento indispensável: quem, então, reunirá os materiais do trabalho, os ingredientes e as ferramentas necessárias à preparação? Quem fará construir canais, empórios, prédios de toda espécie? Quem sustentará até à venda dos couros o grande número de trabalhadores, nenhum dos quais poderia, sozinho, preparar um só couro, e cujo lucro sobre a venda de apenas um couro não poderia dar a subsistência de um só? Quem patrocinaria os custos de instrução dos alunos e aprendizes? Quem lhes daria aquilo com que subsistir até que fossem instruídos, fazendo-os passar, gradativamente, do trabalho fácil e proporcional a suas idades até aos trabalhos que demandam mais força e mais perícia? Este será um dos possuidores de capitais ou de valores mobiliários acumulados, o que os empregará, apoiando-os em parte com investimentos para construções e compra dos materiais, em parte com pagamentos diários aos trabalhadores que se ocupam de prepará-los. É ele o que esperará que a venda dos couros lhe renda não somente todos os seus investimentos, mas ainda lucro suficiente para indenizá-lo do que lhe teria valido seu dinheiro se o tivesse aplicado em aquisição de fundos, e ademais pelo soldo devido por seus trabalhos, por seus cuidados, por seus riscos, por sua perícia mesma; pois sem dúvida a lucros iguais ele teria preferido viver, sem perturbações, da renda de uma terra que poderia ter adquirido com o mesmo capital; à medida que o capital lhe retorne pela venda das obras, ele aplica-o em novas compras para alimentar e sustentar sua fábrica por esse círculo contínuo: ele vive de seus lucros, guarda o que pode poupar para aumentar seu capital e aplicá-lo em sua empresa, aumentando a massa de seus investimentos a fim de aumentar ainda mais seus lucros. 


\section{LXI}

Subdivisão da classe estipendiária industriosa em empreendedores, capitalistas, e em simples trabalhadores.

Toda a classe dedicada a fornecer às diferentes necessidades da sociedade a imensa variedade de obras da indústria se encontra, por assim dizer, dividida em duas ordens: a dos empreendedores manufatureiros, mestres fabricantes, todos possuidores de grandes capitais, que eles aplicam dando trabalho, por meio de seus investimentos, à segunda ordem, que é composta de simples artesãos que não possuem outros bens além de seus braços, que não investem senão seu trabalho diário, que não auferem senão seus salários.

\section{LXII}

Outro emprego dos capitais no investimento de empresas de agricultura. Desenvolvimentos acerca do uso, do retorno e dos lucros indispensáveis dos capitais nas empresas de agricultura.

Falando inicialmente do emprego dos capitais nas empresas de fábrica, tive por propósito apresentar um exemplo mais sensível da necessidade e do efeito de grandes investimentos, e do trajeto de sua circulação: mas inverti um pouco a ordem natural, que demandaria que eu começasse por falar das empresas de cultura, que também não se realizam, não se expandem e não se tornam lucrativas senão por meio de grandes investimentos. São os possuidores de grandes capitais os que, por aplicá-los em empresas de agricultura, cercam as terras e pagam aos proprietários grandes aluguéis, ocupando-se de fazer todos os investimentos da cultura. Seu destino deve ser o mesmo dos empreendedores de fábricas: como eles, devem fazer os primeiros investimentos da empresa, fornecer o gado, cavalos, ferramentas aratórias, comprar as primeiras sementes; como eles, devem manter e alimentar os carreteiros, os ceifeiros, os debulhado- res, os domésticos, trabalhadores de todas as espécies que possuem apenas seus braços, investem apenas seu trabalho e ganham apenas seu salário: como eles, devem recolher, além do retorno de seu capital, isto é, de todos os investimentos primitivos e anuais, $1^{\circ}$. lucro igual à renda que poderiam auferir de seu capital sem nenhum trabalho; $2^{\circ}$. o soldo e o preço do trabalho, dos riscos e da indústria; $3^{\circ}$. o necessário para substituir anualmente o perecimento dos bens móveis usados na empresa, o gado que morre, as ferramentas que usam, etc.; tudo isso deve ser incluído no preço dos produtos da terra; ao cultivador, o excedente serve para pagar ao proprietário a permissão que este lhe deu de servir-se de seu campo para estabelecer sua empresa. É o preço do arrendamento, o rendimento do proprietário, o produto líquido; pois tudo o que a terra produz até ao retorno dos investimentos e dos lucros de todas as espécies daquele que os fez não pode ser visto como um rendimento, mas somente como retorno dos custos da cultura, visto que, se o cultivador não os retirasse, evitaria maximamente empregar suas riquezas e seu esforço cultivando o campo de outrem.

\section{LXIII}

A concorrência entre capitalistas empreendedores de cultura estabelece o preço corrente dos arrendamentos e da grande cultura.

De acordo com a fertilidade da terra e com o preço por que se vendem os produtos, a concorrência entre os ricos empreendedores de cultura estabelece o preço corrente dos arrendamentos, sempre segundo o cálculo que os arrendatários fazem de todos os seus custos e dos lucros que devem retirar de seus investimentos: só podem dar ao proprietário o excedente. Entretanto, quando a concorrência entre eles é muito movimentada, entregam-lhe todo o excedente, não dando o proprietário sua terra senão àquele que lhe oferece $o$ preço mais alto. 


\section{LXIV}

A falta de capitalistas empreendedores de cultura limita a exploração das terras à pequena cultura.

Quando, ao contrário, não há homens ricos que tenham grandes capitais para pôr nas empresas de agricultura, quando, pelo baixo preço dos produtos da terra ou por qualquer outra causa, as colheitas não bastam para garantir aos empreendedores, além do retorno de seus fundos, lucros ao menos iguais aos que retirariam de seu dinheiro se o empregassem de qualquer outro modo, então não se encontram arrendatários que queiram locar as terras. Os proprietários são forçados a fazê-la cultivar por colonos ou por meeiros sem condições de fazer nenhum investimento nem de bem cultivá-las. O proprietário faz por si alguns investimentos medíocres que lhe produzem um rendimento extremamente medíocre: se a terra pertence a um proprietário pobre ou altamente endividado ou negligente, a uma viúva ou a um menor, permanece inculta: tal é o verdadeiro princípio da diferença que destaquei entre as províncias em que a terra é cultivada por arrendatários ricos, como a Normandia e a Ilha de França, e aquelas em que é cultivada apenas por pobres meeiros, como em Limusino, Angoulême, Burbônia e muitas outras.

\section{LXV}

Subdivisão da classe dos cultivadores em empreendedores ou arrendatários e em simples assalariados, servos ou jornaleiros.

Segue-se disso que a classe dos cultivadores se divide, como a dos fabricantes, em duas ordens de homens, a dos empreendedores ou capitalistas que fazem todos os investimentos, e a dos simples trabalhadores assalariados. Vê-se ainda que são os capitais sozinhos os que formam e sustentam as grandes empresas de agricultura, os que dão às terras valor locativo constante, se ouso falar assim, os que garantem aos proprietários um rendimento sempre igual, e o maior possível.

\section{LXVI}

Quarto emprego dos capitais em investimento de empresas de comércio. Necessidade de interposição dos mercadores propriamente ditos entre os produtores e os consumidores.

Os empreendedores, sejam de cultura, sejam de manufatura, retiram seus investimentos e seus lucros apenas pela venda dos frutos da terra ou das obras fabricadas. São sempre as necessidades e as faculdades do consumidor as que põem o preço de venda; mas o consumidor não tem sempre necessidade da coisa fabricada ou produzida no momento da colheita ou do término das obras. No entanto, os empreendedores precisam que seus fundos lhes deem retorno imediata e regularmente para que os vertam novamente em suas empresas: é preciso que os trabalhos e a semente sucedam ininterruptamente à colheita; é preciso ocupar continuamente os trabalhadores de uma manufatura, começar novas obras à medida que as primeiras terminem, substituir os materiais à medida que sejam consumidos: não se interromperiam impunemente os trabalhos de uma empresa instalada, e não seria possível retomá-los a bel-prazer. O empreendedor tem, portanto, o maior interesse em fazer retornar prontamente seus fundos pela venda de suas colheitas ou de suas obras: por outro lado, o consumidor tem interesse em encontrar as coisas de que precisa quando e onde as quiser; ser-lhe-ia demasiadamente incômodo ser obrigado a comprar, no momento da colheita, a provisão de todo um ano. Entre os objetos de consumo imediato, há muitos que exigem longos e dispendiosos trabalhos, trabalhos que não podem ser empreendidos lucrativamente senão com uma quantidade enorme de material, e de tal modo que o consumo de um número muito diminuto de homens ou de um cantão isolado não pode satisfazer o débito das obras de uma só manufatura. As empresas deste tipo de obras existem 
necessariamente em pequeno número, a uma distância considerável uma das outras, e consequentemente muito distantes do domicílio dos grandes consumidores. Não há homens acima da extrema miséria que não possam consumir várias coisas que são colhidas ou fabricadas em lugares muito distantes de si, e não menos distantes uns dos outros. Um homem que não pudesse obter os objetos de seu consumo senão comprando-os imediatamente da mão do que os colhe ou do que os fabrica seria privado de muitas coisas ou dedicaria sua vida a viajar.

O duplo interesse que têm o produtor e o consumidor, o primeiro de encontrar a quem vender, o segundo de encontrar de quem comprar, e no entanto de não perder um tempo precioso esperando o comprador ou procurando o vendedor, fê-los imaginar uma terceira parte a intermediá-los aos dois. E é esse o objeto da profissão dos mercadores, que compram o produto da mão do produtor para fazer estoques ou lojas, às quais o consumidor vem aprovisionar-se. Por esse método, o empreendedor garante a venda e o retorno de seus fundos, ocupa-se sem inquietações nem descanso de novas produções, e o consumidor encontra a seu alcance e a qualquer momento as coisas de que precisa.

\section{LXVII}

Diferentes ordens de mercadores. Todos têm em comum isto: compram para revender; e seu tráfico assenta-se sobre investimentos que devem retornar com lucro para ser novamente vertidos na empresa.

Desde a revendedora que expõe as plantas no mercado até ao armador de Nantes ou de Cádis que estende suas vendas e suas compras até à Índia e à América, a profissão de mercador, ou o comércio propriamente dito, divide-se em uma infinidade de ramos e, por assim dizer, de degraus. Tal mercado pode limitar-se a aprovisionar-se de um ou de vários tipos de produtos, os quais vende em sua butique a todos os que se apresentam. Outro venderá certos produtos no lugar em que são escassos, para conseguir em troca os produtos que lá crescem e faltam no lugar de onde partiu. Um faz suas trocas com os próximos, e por si; outro por meio de correspondentes ou por ministério de condutores a quem paga, envia e faz vir de uma província a outra, de um reino a outro, da Europa à Ásia, da Ásia à Europa. Um vende suas mercadorias, em pequenas partes, a todos os que as consomem; outro vende apenas em grandes quantidades, ao mesmo tempo que as vende a outros mercadores que as revendem a retalhos ao consumidor; mas todos têm em comum que compram para revender, e que suas primeiras compras são um investimento que não retorna senão com o tempo. Deve ter retorno como o dos empreendedores de cultura e de fábrica, não somente por inteiro, em certo tempo, para ser vertido novamente em novas compras, mas também $1^{\circ}$. com lucro igual ao rendimento que se poderia adquirir com capital próprio e sem nenhum trabalho, $2^{\circ}$. com o salário e o preço do trabalho, dos riscos, da indústria. Sem a garantia desse retorno e dos lucros indispensáveis, nenhum mercador empreenderia o comércio nem poderia continuá-lo: é que, deste ponto de vista, ele se pauta, em suas compras, pelo cálculo da quantidade e do preço das coisas que pode esperar vender em certo tempo: o retalhista aprende pela experiência, pelo sucesso das tentativas limitadas, feitas com precaução, qual é, mais ou menos, a quantidade da necessidade dos consumidores que está ao seu alcance fornecer. O negociador instrui-se por suas correspondências sobre o preço, sobre a abundância ou a raridade das mercadorias nas diferentes regiões por que se estende seu comércio; direciona suas especulações em conformidade com isso, envia as mercadorias do lugar em que estão a baixo preço àqueles em que são vendidas mais caro, e naturalmente os custos da condução entram no cálculo dos investimentos que lhe devem retornar.

Já que o comércio é necessário, e que é impossível empreender comércio algum sem investimentos proporcionais à sua extensão, 
eis mais um emprego para as riquezas mobiliárias, um novo uso que o possuidor de uma massa de valor guardada e acumulada, de uma soma de dinheiro, de, em uma palavra, um capital pode fazer para tirar vantagens, para obter sua subsistência e para aumentar, se possível, suas riquezas.

\section{LXVIII}

Verdadeira noção de circulação de dinheiro.

Vê-se, pelo que se acaba de dizer, que a cultura das terras, as fábricas de todo tipo e todos os ramos de comércio se assentam sobre uma massa de capitais ou de riquezas mobiliárias acumuladas que, tendo sido inicialmente investidas pelos empreendedores em cada uma das diferentes classes de trabalho, devem retornar-lhes a cada ano com lucro constante; a saber, o capital para ser vertido e investido novamente na continuação das mesmas empresas, e o lucro para a subsistência mais ou menos confortável dos empreendedores. É tal investimento e tal retorno contínuos de capital o que constitui o que deve ser chamado circulação de dinheiro; tal circulação útil e fecunda é a que anima a todos os trabalhos da sociedade, a que mantém o movimento e a vida no corpo político, e a que dá grandes motivos para compará-la à circulação de sangue no corpo animal. Pois, se, por uma alteração qualquer na ordem dos gastos das diferentes classes da sociedade, os empreendedores cessarem de retirar seus investimentos com o lucro que têm o direito de esperar, é evidente que serão obrigados a diminuir seus empreendimentos; que a quantia de trabalho, a de consumo dos frutos da terra, a de produções e de rendimento serão proporcionalmente diminuídas; que a pobreza tomará o lugar da riqueza, e que os trabalhadores simples, já sem encontrar emprego, cairão na mais profunda miséria.

\section{LXIX}

Todos os empreendimentos de trabalho, sobretudo os de fábrica e os de comércio, eram necessariamente muito limitados antes da introdução do ouro e da prata no comércio.

É quase desnecessário salientar que as empresas de todos os tipos, mas sobretudo as de fábrica, e ainda mais as de comércio, não poderiam senão ser limitadíssimas antes da introdução do ouro e da prata no comércio, já que era quase impossível acumular capitais consideráveis, e ainda mais difícil multiplicar e dividir os pagamentos, na medida em que tal é necessário para facilitar e multiplicar as trocas, na medida em que o exigem um comércio e uma circulação movimentada. Somente a cultura das terras poderia sustentar-se um pouco, porque o gado é o principal emprego dos investimentos que ela exige; é ainda provável que não houvesse outro empreendedor de cultura além do proprietário. Quanto às artes de todas as espécies, não poderiam senão estar na mais extrema languidez antes da introdução do dinheiro. Limitar-se-iam às obras mais grosseiras, nas quais os proprietários faziam os investimentos alimentando os trabalhadores e fornecendo-lhes os materiais, ou às que eram feitas pelos domésticos.

\section{LXX}

Sendo os capitais tão necessários a todos os empreendimentos quanto o trabalho e a indústria, o homem industrioso divide de bom grado os lucros de seu empreendimento com o capitalista que lhe fornece os fundos de que precisa.

Já que os capitais são a base indispensável de todo e qualquer empreendimento lucrativo, já que, com dinheiro, podem montar-se oficinas de costura, estabelecer fábricas, fundar um comércio em que os lucros poupados e acumulados por frugalidade se tornam novamente capitais, já que, em uma palavra, o dinheiro é o principal meio de atrair dinheiro, aqueles que, com indústria e amor ao traba- 
lho, não têm capitais ou não os têm bastantes para os empreendimentos que querem formar não têm dificuldade em contentar-se com ceder, aos possuidores de capitais ou de dinheiro que lhos querem confiar, parte dos lucros que esperam recolher para além do retorno de seus investimentos.

\section{LXXI}

Quinto emprego dos capitais: o empréstimo a juros. Natureza do empréstimo.

Os possuidores de dinheiro comparam o risco que seu capital pode correr caso o empreendimento não logre êxito com a vantagem de gozar sem trabalho de um lucro constante; e pautam-se nisso para exigir mais ou menos de lucro ou de juros sobre seu dinheiro ou para consentir em emprestá-lo mediante os juros que lhe oferece o prestatário. Eis mais uma atividade aberta ao possuidor de dinheiro, o empréstimo a juros ou o comércio de dinheiro. Pois é preciso não enganar-se: o empréstimo a juros é, precisamente, apenas um comércio em que o emprestador é um homem que vende o uso de seu dinheiro, e o recebedor o homem que o compra; precisamente como o proprietário de uma terra e seu arrendatário vendem e compram respectivamente o uso de um fundo arrendado. É isso o que exprimia perfeitamente o nome que os latinos davam aos juros sobre dinheiro emprestado: usura pecunix, palavra cuja tradução francesa se tornou odiosa devido às subsequentes falsas ideias que se fizeram acerca dos juros sobre dinheiro.

\section{LXXII}

Falsas ideias acerca do empréstimo a juros.

O preço do empréstimo não é de modo algum fundado, como se poderia imaginar, sobre o lucro que o recebedor espera auferir com o capital cujo uso ele compra. Esse preço se fixa, como o preço de todas as mercadorias, pelo debate entre o vendedor e o comprador, pelo equilíbrio entre oferta e demanda. Pode emprestar-se com quaisquer condições e por quaisquer motivos. Tal empréstimo para formar uma empresa que fará sua fortuna, tal para comprar uma terra, tal para pagar uma dívida de jogo, tal para complementar a perda do rendimento de que um acidente o privou, tal para sobreviver até que possa ganhar dinheiro por seu trabalho. Mas todos esses motivos que determinam o recebedor são muito diferentes para o emprestador. Este se ocupa apenas de duas coisas, dos juros que receberá e da segurança de seu capital. Ele não se inquieta mais com o uso que fará o recebedor do que um mercador se perturba com o uso que fará o comprador dos produtos que vende.

\section{LXXIII \\ Refutação dos erros dos escolásticos.}

É por não terem examinado o empréstimo a juros de sua verdadeira perspectiva que moralistas, mais rígidos que esclarecidos, o quiseram visto como crime. Os teólogos escolásticos concluíram que, já que o dinheiro não produz nada por si só, seria injusto exigir juros sobre dinheiro emprestado. Tomados de seus preconceitos, acreditaram ver sua doutrina consagrada por esta passagem do evangelho: mutuum date nihil inde sperantes; os teólogos que haviam adotado, acerca da matéria dos juros, princípios mais razoáveis sofreram as mais vivas críticas da parte dos escritores do lado oposto.

No entanto, não é preciso mais que um pouco de reflexão para sentir a frivolidade dos pretextos de que se serviram para condenar o empréstimo a juros. O empréstimo é um contrato recíproco, livre entre as duas partes, e que não é celebrado senão porque lhes é vantajoso. É evidente que, se o emprestador vê uma vantagem em receber um "aluguel" por seu dinheiro, o tomador não está menos interessado em obter o dinheiro de que precisa, já que se dispõe a tomar emprestado e pagar o aluguel desse dinheiro: ora, de acordo com que 
princípio se pode imaginar um crime em um contrato vantajoso para as duas partes em que os dois estão contentes e que certamente não prejudica a ninguém mais? Dizer que o emprestador, para exigir juros, abusa da necessidade de dinheiro do tomador é dizer tanta absurdidade como se se dissesse que um padeiro que exige dinheiro em troca do pão que vende abusa da necessidade que tem o comprador. Se neste último caso o dinheiro é equivalente ao pão que recebe o comprador, o dinheiro que o tomador recebe hoje é também equivalente ao capital e aos juros que ele promete devolver em certo tempo; pois, afinal, é uma vantagem para o tomador ter, nesse intervalo, o dinheiro de que precisa, e é uma desvantagem para o emprestador ser privado dele. A desvantagem é mensurável, e é mensurada; os juros são o preço. O preço deve ser ainda maior se o emprestador corre risco de perder seu capital pela insolvência do tomador. O negócio é, portanto, perfeitamente igual de parte a parte, e consequentemente legítimo. O dinheiro considerado como uma substância física, como uma massa de metal, não produz nada; mas o dinheiro empregado em investimentos de empresas de cultura, de fábricas, de comércio alcança lucro certo; com o dinheiro, pode adquirir-se uma terra e obter uma renda: aquele que empresta dinheiro não cede, portanto, unicamente a posse estéril do dinheiro, mas priva-se do lucro ou do rendimento que poderia ter obtido, e os juros que o indenizam dessa privação não poderiam ser visto como injusto. Os escolásticos, forçados a render-se a essas considerações, permitiram que se retirassem juros do dinheiro desde que se alienasse o capital, isto é, desde que o emprestador renunciasse a exigir o reembolso de seu dinheiro em certo tempo, e deixasse o tomador como dono, a guardá-lo tanto quanto quisesse e pagando apenas os juros. A razão desta tolerância era que, assim, já não se tratava de um dinheiro emprestado de que se retiravam juros, era uma renda que se comprava por uma soma em dinheiro, como se compra uma terra. Era uma pequena sutileza à qual recorreram para ceder à necessidade absoluta de empréstimo no curso dos negócios da sociedade sem confessar abertamente a falsidade dos princípios sobre os quais o tinham condenado; mas tal cláusula de alienação do capital não é uma vantagem para o tomador, que não fica menos responsável pela dívida até que tenha reembolsado tal capital, e cujos bens estão sempre vinculados à segurança de tal capital. É até uma desvantagem, já que, quando necessita, ele encontra dinheiro para empréstimo muito mais dificilmente; pois aquele que consentiria de bom grado em emprestar durante um ou dois anos uma soma que ele destinaria a comprar uma terra não quererá emprestá-lo por tempo indefinido. Além disso, se se pode vender seu dinheiro por uma renda perpétua, por que não se poderia alugá-lo por alguns anos, em troca de uma renda que duraria apenas esse mesmo número de anos? Se uma renda de mil francos por ano é equivalente a uma soma de vinte mil francos para aquele que guarda esta soma perpetuamente, mil francos serão, a cada ano, equivalentes à posse de tal soma durante um ano.

\section{LXXIV \\ Verdadeiro fundamento dos juros sobre dinheiro.}

Pode alugar-se, portanto, dinheiro tão legitimamente quanto se pode vender dinheiro; e o possuidor do dinheiro pode fazer um e outro; não somente porque o dinheiro é equivalente a uma renda ou a um meio de obter renda; não somente porque o emprestador perde, durante o tempo do empréstimo, a renda que teria podido obter; não somente porque arrisca seu capital; não somente porque o tomador pode empregá-lo com aquisições vantajosas ou em empreendimentos de onde tiraria grandes lucros: o proprietário do dinheiro pode legitimamente cobrar juros por ele, e isso por um princípio mais geral e mais decisivo. Se nada disso fosse legítimo, ainda assim ele não estaria menos em seu direito de exigir juros sobre o empréstimo pela simples razão de que seu dinheiro lhe pertence a ele. Já que lhe pertence a ele, ele é livre para guardá-lo; nada o obriga a emprestá-lo: se então 
o empresta, pode atribuir a seu empréstimo a condição que quiser. Não faz com isso mal algum ao tomador, já que este se submete a tal condição e não tem nenhuma espécie de direito sobre a soma emprestada. O lucro que se pode obter com o dinheiro é sem dúvida um dos motivos mais frequentes que levam o tomador ao empréstimo com juro; é uma das fontes da facilidade que ele tem pra pagar esses juros, mas não é de modo algum o que dá direito ao emprestador de exigi-lo; basta para isso que seu dinheiro lhe pertença, e este direito é inseparável de sua propriedade. Aquele que compra o pão tem por motivo alimentar-se; mas o direito que tem o padeiro de exigir um preço por ele é completamente independente deste uso do pão: é o mesmo direito o que ele teria de vender-lhe pedras; direito fundado unicamente no fato de que, pertencendo-lhe o pão, ninguém tem o direito de obrigá-lo a dá-lo por nada.

\section{LXXV \\ Resposta a uma objeção.}

Esta reflexão nos leva a sentir quanto a aplicação feita pelos rigoristas da passagem $m u$ tuum date, nihil inde sperantes (Emprestai sem esperança de lucro) é falsa e se afasta do sentido do Evangelho. Esta passagem é clara quando a tomamos, como os teólogos moderados e razoáveis, como um preceito de caridade. Todos os homens devem socorrer-se uns aos outros: um homem rico que, vendo seu semelhante na miséria, em vez de atender a suas necessidades, lhe vendesse seu socorro, faltaria ao dever do cristianismo e aos da humanidade. Em tais circunstâncias, a caridade não somente prescreve emprestar sem juros, senão que ordena emprestar, e dar se necessário for. Fazer desse preceito de caridade um preceito de justiça rigorosa é ofender igualmente a razão e o sentido do texto. Aqueles que ataco aqui não pretendem que emprestar seu dinheiro seja um dever de justiça; é preciso, portanto, que concordem em que as primeiras palavras da passagem, $m u_{-}$ tuum date, não encerram senão um preceito de caridade: ora, pergunto então por que querem que do fim da passagem se entenda um dever de justiça. Quê! O empréstimo mesmo não será preceito rigoroso, e o acessório, a condição do empréstimo, o será! Ter-se-á dito aos homens: "É-vos" permitido emprestar ou não, "mas, se o fizerdes, abstende-vos" de retirar quaisquer juros sobre vosso dinheiro, e, "ainda que um negociante vo-lo" demande para um empreendimento de que espera tirar grandes lucros, "seria um crime aceitardes" os juros que ele vos oferece; é preciso, "necessariamente, ou emprestar-lhe dinheiro gratuitamente", ou não emprestar-lhe de todo. Vós tendes, "na verdade, um meio de tornar os juros" legítimos, ou seja, emprestar vosso capital por "tempo indefinido, e renunciar a exigir o reembolso" que vosso devedor vos fará quando quiser, ou quando puder. Se com isso encontrardes inconvenientes acerca da "segurança, ou se prevedes que tereis necessidade de vosso dinheiro em "certo número de anos, não tendes outra opção além de não emprestá-lo: mais vale deixar passar a este" negociante a oportunidade mais preciosa que cometer um pecado para "facilitar-lha". Aí está o que se leu nestas cinco palavras, mutuum date, nihil inde sperantes, quando as leram com os preconceitos que oferecia uma falsa metafísica. Todo e qualquer homem que ler esse texto sem prevenções verá nele o que nele está, isto é: como homens, como cristãos, sois todos irmãos, todos amigos: tratai-vos como irmãos e como amigos; socorrei-vos em vossas necessidades; que vossas bolsas estejam abertas umas às outras, e não vendas os socorros que vos deveis reciprocamente exigindo juros sobre um empréstimo de que a caridade vos faz um dever. É este o verdadeiro sentido da passagem em questão. A obrigação de emprestar sem juro, e a de emprestar, são evidentemente relativas uma à outra; são da mesma ordem, e ambas anunciam um dever de caridade, não um preceito de justiça rigorosa, aplicável a todos os casos em que se pode emprestar².

\footnotetext{
2 O autor comete, aqui, um erro de má metafísica ou de má lógica. Com efeito, supõe que possa haver duas justiças, uma natural e outra da caridade, que se contradigam, o que é tão impossível como haver duas
} 


\section{LXXVI}

A taxa dos juros não deve ser fixada, assim como a de todas as mercadorias, senão pelo próprio curso do comércio.

Já disse que o preço do dinheiro emprestado se assenta, como o de todas as outras mercadorias, no equilíbrio da oferta e da demanda: assim, quando há muitos tomadores de empréstimo com necessidade de dinheiro, os juros sobre o dinheiro tornam-se mais altos; quando há muitos possuidores de dinheiro que o oferecem em empréstimo, os juros baixam. É, portanto, outro erro crer que os juros sobre o dinheiro devem, no comércio, ser fixados pelas leis dos príncipes. É um preço corrente, fixado como o de todas as outras mercadorias. Este preço é um pouco diferente, segundo tenha o emprestador mais ou menos segurança de não perder seu capital; mas, com igual segurança, ele deve aumentar ou baixar segundo a abundância ou a necessidade; e a lei não deve fixar a taxa de juros do dinheiro mais do que deve taxar todas as outras mercadorias que correm no comércio.

\section{LXXVII}

O dinheiro tem, no comércio, duas avaliações: uma exprime a quantidade de dinheiro que se dá para obter os diferentes tipos de produtos; outra exprime a relação de uma soma de dinheiro com os juros que ela obtém conforme o curso do comércio.

verdades que se contradigam. Por isso é que as palavras evangélicas concernentes à usura não constituem conselho, mas preceito geral: e preceito implica dever. Não por nada, aliás, todos os filósofos pagãos condenaram o empréstimo a juros. Santo Tomás, o Doutor Comum, não poderia fazer senão o mesmo, e decididamente; mas considera duas coisas. Antes de tudo, no relativo à prudência política, admite que a lei humana tolere os juros (cf. Suma Teológica, q. 78, a. 1, ad $3)$. Depois, diz que é lícito a um prestamista reclamar parte do lucro alcançado graças a seu dinheiro - desde que o tenha emprestado a modo de sociedade (cf. ibid., q. 78, a. 2, ad 5). [N. dos T.]
Parece, pelo desenvolvimento da maneira pela qual o dinheiro se vende ou se aluga mediante juros anuais, que há duas maneiras de avaliar o dinheiro no comércio. Nas compras e nas vendas, certo peso de dinheiro representa certa quantidade de valores ou de mercadorias de cada espécie: por exemplo, uma onça de dinheiro equivale a certa quantidade de trigo, ou a certo número de jornadas de um homem. No empréstimo e comércio de dinheiro, um capital é equivalente a uma renda igual a determinada porção de tal capital; e, reciprocamente, uma renda anual representa um capital igual ao montante dessa renda repetida certo número de vezes, segundo os juros estejam mais ou menos altos.

\section{LXXVIII}

Estas duas avaliações são independentes uma da outra, e se assentam em princípios completamente diferentes.

Estas duas apreciações têm muito menos relação entre si e dependem muito menos uma da outra do que se estaria tentado a crer à primeira vista. $\mathrm{O}$ dinheiro poderia ser muitíssimo comum no comércio ordinário, ter nele pouquíssimo valor, corresponder a quantidade mínima de produtos, e, ainda assim, os juros sobre o dinheiro poderiam ser altíssimos.

Suponha-se que, tendo um milhão de onças correndo atualmente no comércio, uma onça se troque por uma medida de trigo. Suponha-se que surja no Estado, por qualquer razão, um segundo milhão de onças, e que esse aumento se distribua entre todos segundo a mesma proporção do primeiro milhão, de modo que aquele que possuía anteriormente duas onças tenha agora quatro. $\mathrm{O}$ dinheiro, considerado como massa de metal, diminuirá certamente de preço, ou, o que dá no mesmo, os produtos estarão mais caros; e será preciso, para ter a mesma quantidade de trigo que se tinha com uma onça, dar mais dinheiro, talvez duas onças em vez de uma. Mas de ne- 
nhum modo se seguirá disso que os juros sobre o dinheiro baixem, se todo esse dinheiro é levado ao mercado e usado nas despesas correntes daqueles que o possuem, como o era, por suposição, com o primeiro milhão de onças; pois os juros sobre o dinheiro não baixam senão na proporção em que haja mais dinheiro por emprestar - segundo a necessidade dos tomadores de empréstimo - que havia antes. Ora, o dinheiro que se leva ao mercado não é para emprestar; o dinheiro guardado é que é o que capital acumulado que se empresta; e o aumento do dinheiro no mercado, ou a diminuição de seu preço em face dos produtos do comércio ordinário, estão muito longe de trazer, infalivelmente, e por relação imediata, a diminuição dos juros sobre o dinheiro; pode acontecer, ao contrário, que a causa mesma do aumento da quantidade de dinheiro no mercado, e que aumenta o preço dos outros produtos baixando o preço do dinheiro, seja precisamente a que aumenta o aluguel do dinheiro, ou a taxa de juros.

Com efeito, suponha-se por um momento que todos os ricos de uma nação, em vez de poupar seus rendimentos ou seus lucros anuais, os gastem completamente; que, não contentes com gastar todo o seu rendimento, gastem seu capital; que um homem que tenha cem mil francos em dinheiro, em vez de empregá-los de maneira lucrativa ou de emprestá-los, os consuma gradualmente em gastos desajuizados: é visível que, de um lado, haverá mais dinheiro empregado em compras comuns, para satisfação das necessidades ou fantasias de cada particular, e que, por consequência, ele baixará de preço; de outro lado, haverá certamente muito menos dinheiro para emprestar; e, como muitas pessoas se arruinarão, haverá provavelmente tanto mais tomadores de empréstimo. Os juros sobre o dinheiro, portanto, aumentarão, ao mesmo tempo que o dinheiro se tornará mais comum no mercado e baixará de preço, e isso precisamente pela mesma causa.

Cessaremos de surpreender-nos com essa aparente extravagância quando considerarmos que o dinheiro ofertado no mercado em troca de trigo é aquele que se gasta diariamente para satisfazer nossas necessidades, e que aquele que se oferta para empréstimo é precisamente aquele que separamos de nossos gastos diários para guardá-lo ou para formar capital.

\section{LXXIX}

Na avaliação do dinheiro comparado com produtos, o dinheiro é considerado metal que é objeto de apreciação. Na avaliação do denier do dinheiro, é o uso do dinheiro por um tempo determinado o que é objeto de apreciação.

No mercado, compra-se uma porção de trigo por certo volume de dinheiro; ou compra-se uma quantidade de dinheiro por esse produto; mas é essa quantidade mesma o que se aprecia e se compara com outros valores estranhos. No empréstimo a juros, o objeto de apreciação é o uso de certa quantidade de valores durante certo tempo. Já não é uma massa de dinheiro que se compara a uma massa de trigo; é uma massa de valores que se compara a determinada porção dela mesma, e que se torna o preço do uso dessa massa durante certo tempo. Que vinte mil onças sejam equivalentes, no mercado, a vinte mil porções de trigo, ou somente a dez mil; mas o uso dessas vinte mil onças durante um ano não valerá menos, no mercado de empréstimos, que a vigésima parte da soma principal, ou mil onças, se os juros forem de cinco por cento 3 .

\section{LXXX}

O preço dos juros depende diretamente da relação entre a demanda dos tomadores de empréstimo e a oferta dos emprestadores, e essa relação depende principalmente da quantidade de riquezas mobiliárias acumuladas com a economia dos rendimentos e dos produtos anuais para formar capitais, sejam capitais existentes em dinheiro ou em qualquer outro gênero de bens que tenham valor no comércio.

\footnotetext{
${ }^{3}$ No original, au denier vingt. [N. dos T.]
} 
O valor do dinheiro no mercado só guarda correlação com a quantidade do metal empregado nas trocas correntes; mas a taxa de juros correlaciona-se com a quantidade de valores acumulados e poupados para formar capitais. É indiferente que os valores sejam em metal ou em outros bens, desde que os bens sejam de fácil conversão em dinheiro. Também é preciso que o volume de moeda que exista em um Estado seja tão grande quanto a soma dos valores que são emprestados a juros no decorrer de um ano: mas todos os capitais em móveis, em mercadorias, em ferramentas, em gado substituem esse dinheiro, o representam. O papel assinado por um homem que sabidamente possui bens equivalentes a cem mil francos, e que promete pagar os cem mil francos em certa data, faz, até tal data, as vezes de cem mil francos; todos os capitais daquele que assinou a nota respondem pelo pagamento, seja qual for a natureza dos bens que ele tem em sua posse, desde que tenham o valor de cem mil francos. Não é, portanto, a quantidade de dinheiro existente como moeda o que faz aumentar ou diminuir os juros sobre o dinheiro, ou que, no comércio, aumenta a quantidade de dinheiro oferecido para empréstimo; é unicamente a soma de capitais existente no comércio, isto é, a soma efetiva de valores mobiliários de todas as espécies, acumulados, poupados sucessivamente sobre as rendas e sobre os lucros, para renderem ao possuidor novos rendimentos e novos lucros. São essas poupanças acumuladas as que são oferecidas aos tomadores; e, quanto mais as há, mais os juros sobre o dinheiro são baixos, a menos que o número de tomadores aumente proporcionalmente.

\section{LXXXI}

O espírito de economia de uma nação aumenta incessantemente a soma de capitais; o luxo tende incessantemente a destruí-los.

O espírito de economia de uma nação tende a aumentar incessantemente a soma de seus capitais, a aumentar o número de em- prestadores, a diminuir o de tomadores. O vezo do luxo produz precisamente o efeito contrário; e, pelo que já foi dito sobre o uso dos capitais em todos os empreendimentos, de cultura, de indústria e de comércio, pode julgar-se se o luxo enriquece uma nação ou se a empobrece.

\section{LXXXII}

A diminuição dos juros prova que, em geral, a economia na Europa prevaleceu sobre o luxo.

Já que os juros sobre o dinheiro diminuíram incessantemente na Europa ao longo de alguns séculos, conclui-se necessariamente que o espírito de economia é mais generalizado que o espírito do luxo. Não há senão gente já rica que se entregue ao luxo; e, entre os ricos, todos aqueles que são razoáveis se limitam a gastar seu rendimento, tomando cuidado para não atentar contra seus capitais. Os que querem enriquecer são muito mais numerosos que os já ricos; ora, no estado atual de coisas, no qual todas as terras estão ocupadas, não há senão um meio de tornar-se rico: ter ou obter, de alguma maneira, uma renda ou um lucro anual além do necessário absoluto para sua subsistência, e todos os anos guardar esse excedente, para com ele formar um capital por meio do qual se possa obter um aumento de renda ou de lucro anual que possa mais uma vez poupar-se e converter-se em capital. Há, assim, grande número de homens interessados e ocupados em amealhar capitais.

\section{LXXXIII}

Recapitulação das cinco maneiras de empregar os capitais.

Contei cinco maneiras de empregar os capitais, ou de alocá-los de maneira lucrativa.

A primeira é comprar um fundo de terras que produza certo rendimento.

A segunda é alocar o dinheiro em empreendimentos de cultura, arrendando as ter- 
ras cujos frutos devem render, além do preço do arrendamento, os juros dos investimentos e o preço do trabalho daquele que consagra a essa cultura suas riquezas e seu esforço.

A terceira é alocar seu capital em empresas de indústria ou de fábrica.

A quarta, alocá-lo em empreendimentos de comércio.

E a quinta, emprestá-lo àqueles que necessitem mediante juros anuais.

\section{LXXXIV \\ Influências dos diferentes empregos de dinheiro entre si.}

É evidente que os produtos anuais que se podem retirar dos capitais alocados nesses diferentes empregos são limitados uns pelos outros e relativos, todos, à taxa efetiva dos juros sobre o dinheiro.

\section{LXXXV \\ $O$ dinheiro alocado em terras deve render menos.}

Aquele que aloca seu dinheiro comprando uma terra arrendada a um fazendeiro sabidamente solvente obtém para si um rendimento que lhe dá pouquíssimo esforço para recebê-lo, e que ele pode despender da maneira que lhe seja mais agradável, dando vazão a todos os seus gostos. Mais: ele tem a vantagem de adquirir aquele de todos os bens cuja posse é a mais segura contra todas as sortes de acidentes. Comprar-se-á mais onerosamente, portanto, um rendimento igual em terras, ou se ficará contente com uma renda menor por capital igual.

\section{LXXXVI}

$O$ dinheiro emprestado deve render um pouco mais que o rendimento das terras adquiridas por capital igual.

Aquele que empresta seu dinheiro a juros se compraz ainda mais tranquilamente e mais livremente que o possuidor de terras; mas a insolvência de seu devedor pode fazê-lo perder seu capital. Ele não se contentará, portanto, com juros iguais ao rendimento da terra que poderia comprar com o mesmo capital. Os juros sobre o dinheiro emprestado devem ser, assim, maiores que o rendimento de uma terra comprada pelo mesmo capital; pois, se o emprestador tivesse a oportunidade de comprar uma terra de igual rendimento, preferiria este emprego.

\section{LXXXVII}

$O$ dinheiro alocado em empreendimentos de cultura, de fábrica e de comércio deve render mais que os juros sobre o dinheiro emprestado.

Por razão semelhante, o dinheiro empregado na agricultura, na indústria e no comércio deve produzir lucro mais considerável que o rendimento do mesmo capital empregado em terras ou que os juros do mesmo dinheiro emprestado; pois que, exigindo esses empregos, além do capital investido, muita dedicação e muito trabalho, se não fossem mais lucrativos, valeria muito mais a pena obter um rendimento igual que se pudesse gozar sem nada ter de fazer. É preciso, portanto, que, além dos juros de seu capital, o empreendedor retire a cada ano um lucro que o recompense por sua dedicação, por seu trabalho, por seus talentos, por seus riscos, e que ainda lhe forneça meios suficientes para reparar o perecimento anual de seus investimentos, os quais é obrigado a converter, desde o primeiro momento, em bens suscetíveis de transformação e expostos a todas as sortes de acidentes.

\section{LXXXVIII}

Não obstante, os produtos desses diferentes empregos limitam-se uns aos outros, e mantêm-se, apesar de suas diferenças, em uma espécie de equilíbrio. 
Os diferentes empregos de capitais resultam, assim, em produtos muito diferentes; mas essa diferença não impede que se influenciem uns aos outros, reciprocamente, nem que se estabeleça entre eles uma espécie de equilíbrio, como entre dois líquidos de pesos diferentes que se comunicassem pela base de um sifão invertido, cujos dois dutos ocupariam: não estariam nivelados, mas a altura de um não poderia aumentar sem que a do outro também aumentasse no duto oposto. Suponha-se que de súbito enorme número de proprietários de terra queira vendê-las. É evidente que o preço das terras baixará, e que com uma soma menor se adquirirá maior rendimento: isso não pode acontecer sem que os juros sobre o dinheiro se tornem mais altos, pois os possuidores de dinheiro desejarão antes comprar as terras que emprestar a juros que não seriam tão grandes como o rendimento das terras que comprassem. Se, assim, os tomadores de empréstimos quiserem ter dinheiro, serão obrigados a pagar por ele um aluguel maior. Se os juros sobre o dinheiro se torna mais alto, desejar-se-á antes emprestá-lo que explorá-lo de modo mais penoso e mais arriscado em empreendimentos de cultura, de indústria e de comércio, e não se farão empreendimentos que não produzam, além dos salários do trabalho, um lucro bem maior que a taxa de dinheiro emprestado. Em uma palavra, tão logo os lucros resultantes de um emprego qualquer de dinheiro aumentem ou diminuam, os capitais dirigem-se a ele saindo dos outros empregos, ou dele se retiram dirigindo-se a outros empregos; coisa que faz necessariamente mudar, em cada um desses empregos, a relação entre capital e produção anual. Em geral, o dinheiro convertido em fundo de terra produz menos que o dinheiro emprestado, e o dinheiro emprestado produz menos que o dinheiro empregado em empreendimentos laboriosos, mas o produto do dinheiro empregado, de qualquer maneira, não pode aumentar ou diminuir sem que os outros empregos experimentem aumento ou diminuição proporcional.

\begin{abstract}
LXXXIX
A taxa corrente de juros sobre o dinheiro é o termômetro por que se podem julgar a abundância ou a escassez de capitais; é a medida da extensão que uma nação pode dar a seus empreendimentos de cultura, de fábrica e de comércio.
\end{abstract}

A taxa corrente de juros sobre o dinheiro emprestado pode, assim, ver-se como uma espécie de termômetro da abundância ou da escassez dos capitais dentro de uma nação, bem como da extensão dos empreendimentos de todas as espécies a que ela pode dedicar-se: é evidente que, quanto mais baixos são os juros, mais têm valor as terras. Um homem que tenha cinquenta mil libras de rendas, se as terras se vendem pelo vigésimo denier, não tem senão uma riqueza de um milhão; terá dois milhões se as terras se vendem pelo quadragésimo denier. Se os juros estão a cinco por cento, toda e qualquer terra por decruar cujos produtos não rendam cinco por cento, além da manutenção dos investimentos e da recompensa pela dedicação dos cultivadores, permanecerá inculta. Toda e qualquer fábrica e todo e qualquer comércio que não rendam cinco por cento, além da recompensa pelos esforços e pelos riscos do empreendedor, não existirão. Se houver uma nação vizinha em que os juros estejam apenas a dois por cento, não somente ela fará todos os negócios de que a nação de juros a cinco por cento se encontre excluída, mas ainda seus fabricantes e seus negociantes, podendo contentar-se com um lucro menor, estabelecerão seus produtos a mais baixos preços em todos os mercados, e atrairão para si o comércio quase exclusivo de todas as coisas cujas circunstâncias particulares, ou o excessivo alto preço dos custos de transporte, as afastam da nação em que o dinheiro vale cinco por cento.

\section{$\mathrm{XC}$}

Influência da taxa de juros sobre todas as empresas lucrativas. 
Pode-se ver o valor dos juros como uma espécie de nível abaixo do qual todo e qualquer trabalho, toda e qualquer cultura, toda e qualquer indústria, todo e qualquer comércio cessam. É como um mar que se expande sobre uma vasta porção de terra; o cimo das montanhas eleva-se sobre a água e forma ilhas férteis e cultivadas. Se esse mar vem a escoar, à medida que ele desça, os terrenos em declive, depois planícies e vales aparecerão e se cobrirão de produtos de todas as espécies. Basta que a água suba ou desça um pé para ou inundar ou oferecer à cultura plagas imensas. É a abundância dos capitais o que anima a todas as empresas; e os baixos juros sobre o dinheiro são ao mesmo tempo efeito e índice da abundância de capitais.

\section{$\mathrm{XCI}$}

A riqueza total de uma nação é composta $1^{\stackrel{o}{ }}$. do rendimento líquido de todos os bens imóveis multiplicado pela taxa do preço das terras; $2^{\circ}$. da soma de todas as riquezas mobiliárias existentes em uma nação.

Os bens imóveis equivalem a um capital igual à sua renda anual multiplicada pelo denier corrente por que são vendidas as terras. Assim, se se somasse a renda de todas as terras, isto é, a renda líquida que dão aos proprietários e a todos os que partilham sua propriedade, como o senhor que percebe uma renda, o cura que percebe o dízimo, o soberano que percebe o imposto; se, digo eu, se somassem todos esses valores e os multiplicássemos pela taxa por que são vendidas as terras, teríamos a soma das riquezas de uma nação em bens imóveis. Para obter a totalidade das riquezas de uma nação, é preciso acrescentar-lhe a ela as riquezas mobiliárias, que consistem na soma dos capitais empregados em todos os empreendimentos de cultura, de indústria e de comércio, e que deles não saem jamais, e todos os investimentos em todos os gêneros de empreendimento que devem retornar incessantemente aos empreen- dedores para ser incessantemente vertidos no empreendimento, que, sem isso, não poderia ter prosseguimento. Seria um erro dos mais grosseiros confundir a imensa massa dessas riquezas mobiliárias com a massa de dinheiro que existe em um Estado; comparativamente, esta não é senão um objeto muito pequeno. Basta, para convencer-se disso, representar a imensa quantidade de gado, de ferramentas, de sementes que constituem os investimentos da agricultura; de materiais instrumentais, de móveis, de mercadorias de todas as espécies que preenchem as oficinas, as lojas e estabelecimentos de todos os manufaturadores, de todos os mercadores e de todos os comerciantes; e aí se sentirá que, na totalidade das riquezas, sejam imóveis, sejam mobiliárias, de uma nação, o dinheiro em espécie não é senão pequeníssima parte. Sendo porém todas essas riquezas e todo esse dinheiro continuamente permutáveis, todas representam o dinheiro, e o dinheiro representa a todas.

\section{XCII}

O valor dos capitais emprestados não poderia compreender-se aí sem que fosse duplamente computado.

É preciso não compreender, no cálculo das riquezas da nação, o valor dos capitais emprestados; pois esses capitais não puderam ser emprestados senão a proprietários de terras ou a empreendedores para que os explorassem em seus empreendimentos, já que somente esses dois tipos de pessoas podem responder pelo capital e pagar os juros: um dinheiro emprestado a pessoas que não tenham fundos nem indústria seria um capital extinto, e não um capital empregado. Se o proprietário de uma terra de quatrocentos mil francos toma cem emprestados, seu bem incumbe-se de uma renda que diminui seu rendimento na mesma medida; e, se vendesse seu bem, dos quatrocentos mil francos que receberia, cem pertenceriam ao emprestador. O capital do emprestador formaria, assim, no cálculo das riquezas existentes, um duplo 
cômputo com uma parte igual de valor da terra. A terra vale sempre quatrocentos mil francos: quando o proprietário toma emprestados cem mil francos, isso não a faz valer quinhentos mil francos, senão que faz apenas que, dos quatrocentos mil francos, cem pertençam ao emprestador, e que não pertençam mais de trezentos ao tomador.

Ocorreria o mesmo duplo cômputo se se fizesse entrar no cálculo total de capitais o dinheiro emprestado a um empreendedor para que se empregasse nos investimentos de sua empresa; porque este empréstimo não aumenta a soma total dos investimentos necessários à empresa, sucede apenas que essa soma e a parte dos lucros que os juros representam pertencem ao emprestador. Quer um comerciante empregue dez mil francos próprios em seu comércio e tire daí todo o lucro, quer tenha tomado emprestados esses dez mil francos a outro, ao qual paga juros, contentando-se com o excedente do lucro e com o soldo de sua indústria, tais francos nunca são mais que dez mil francos.

Se todavia não se pode incluir, sem cair em duplo cômputo, o capital dos juros sobre empréstimo no cálculo das riquezas de uma nação, deve nele incluir todos os outros bens móveis que, ainda que formem originariamente um objeto de despesa e não tragam nenhum lucro, se tornam, no entanto, por sua durabilidade, verdadeiro capital que se acumula incessantemente e que, podendo, em caso de necessidade, ser trocado por dinheiro, forma um como fundo de reserva que pode entrar no comércio e suprir, quando se quiser, a perda de outros capitais. Tais são os móveis de todas as espécies, as joias, a baixela, os quadros, as estátuas, o dinheiro indefectível trancado no cofre dos avaros: todas essas coisas têm valor, e a soma de todos esses valores pode ser um objeto considerável nas nações ricas: mas, considerável ou não, é sempre verdadeiro que ele deve ser contado junto com a soma do preço dos bens imóveis e com a dos investimentos circulantes nos empreendimentos de todos os tipos, para formar a soma total das riquezas de uma nação. De resto, não é necessário dizer que, ainda que se possa muito bem definir, como se acaba de fazer, em que consiste a totalidade das riquezas de uma nação, é provavelmente impossível descobrir a quanto exatamente elas montam; a menos que se encontre alguma regra para fixar a proporção do comércio total de uma nação com o rendimento de suas terras: coisa talvez factível, mas que não foi ainda executada de maneira que se encerrem todas as dúvidas.

\section{XCIII}

Em qual das três classes da sociedade se devem incluir os capitalistas que emprestam dinheiro?

Vejamos agora como o que acabamos de desenvolver sobre as diferentes maneiras de empregar os capitais se concilia com o que estabelecemos anteriormente acerca da divisão de todos os membros da sociedade em três classes, a classe produtora ou dos agricultores, a classe industriosa ou comerciante, e a classe disponível ou dos proprietários.

\section{XCIV}

\section{O capitalista que empresta dinheiro pertence, quanto a sua pessoa, à classe disponível.}

Vimos que todo e qualquer homem rico é necessariamente possuidor ou de um capital em riquezas mobiliárias, ou de um fundo equivalente a um capital. Todo e qualquer fundo de terra equivale a um capital; assim, todo e qualquer proprietário é capitalista, mas nem todo e qualquer capitalista é proprietário de bens imóveis; e o possuidor de um capital mobiliário tem a escolha ou de empregá-lo para adquirir fundos, ou de explorá-lo em empreendimentos da classe cultivadora ou da classe industriosa. O capitalista, uma vez empreendedor de cultura ou de indústria, já não é mais disponível, nem ele nem seus lucros, que o simples trabalhador dessas duas classes; ambos se aplicam à continuação de 
seus empreendimentos. O capitalista que se reduz a mero emprestador de dinheiro, esse ou empresta a um proprietário ou empresta a um empreendedor. Se empresta a um proprietário, parece pertencer à classe dos proprietários; torna-se sócio na partilha da propriedade; o rendimento da terra é dedicado ao pagamento dos juros de seu credor; o valor do fundo é dedicado à segurança de seu capital até à devida quitação. Se se empresta a um empreendedor, é certo que a pessoa do emprestador pertence à classe disponível; mas seu capital permanece dedicado aos investimentos do empreendimento, e não pode ser retirado de lá sem prejudicá-lo ou sem ser substituído por capital de igual valor.

\section{$\mathrm{XCV}$}

Os juros que retira o emprestador estar disponíveis quanto ao uso que se pode fazer dele.

Na verdade, os juros que ele tira desse capital parecem estar disponíveis, já que o empreendedor e o empreendimento podem prescindir deles; e também parece que se pode concluir que há, nos lucros das duas classes laboriosas empregados seja na cultura seja na indústria, uma porção disponível, a saber, a que responde pelos juros dos investimentos calculados segundo os juros correntes; e parece ainda que essa conclusão atende àquilo que dissemos, que somente a classe dos proprietários possui rendimento propriamente dito, rendimento disponível, e que todos os membros das outras duas classes não possuem mais que soldos ou lucros. Isto merece esclarecimento. Se se consideram os mil em espécie que retira todo ano um homem que emprestou sessenta mil francos a um comerciante em relação ao uso que ele pode fazer dele, não há dúvida de que eles estão perfeitamente disponíveis, já que a empresa pode prescindir deles.

\section{XCVI}

Os juros sobre o dinheiro não estão disponíveis no sentido de que o Estado possa sem inconvenientes apropriar-se de parte dele para suas necessidades.

Mas não se segue que estejam disponíveis no sentido de que o Estado possa apropriar-se impunemente de uma porção para suas necessidades públicas. Esses mil em espécie não são uma retribuição que a cultura ou o comércio dão gratuitamente àquele que fez os investimentos; é o preço e a condição desse investimento, investimento sem o qual o empreendimento não poderia subsistir. Se essa retribuição é diminuída, o capitalista retirará seu dinheiro, e o empreendimento cessará. Essa retribuição deve, portanto, ser sagrada e gozar de total imunidade, porque é o preço de um investimento feito no empreendimento, sem o qual o empreendimento não poderia subsistir. Tocá-lo seria aumentar o preço dos investimentos de todas as empresas, e consequentemente diminuir os empreendimentos mesmos, isto é, a cultura, a indústria e o comércio. Esta resposta nos deve fazer concluir que, se dissemos que o capitalista que empresta a um proprietário parece pertencer à classe proprietária, tal aparência tem algo de equívoco e precisa esclarecer-se. Com efeito, é precisamente verdadeiro que os juros de seu dinheiro não estão mais disponíveis, isto é, não são mais suscetíveis de supressão que os do dinheiro emprestado aos empreendedores de cultura ou de comércio. Estes juros são igualmente o preço da convenção livre, e não é possível suprimi-los sem alterar ou mudar o preço do empréstimo: ora, pouco importa a quem o empréstimo se fez; se o preço do empréstimo muda e aumenta para o proprietário, mudará e aumentará para o cultivador, para o manufaturador e para o comerciante. Em uma palavra, o capitalista que empresta dinheiro deve ser considerado como um mercador de um produto absolutamente necessário à produção das riquezas e que não poderia estar a um preço excessivamente baixo. É tão desarrazoado onerar seu comércio com um imposto quanto pôr um imposto so- 
bre o estrume que serve para adubar as terras. Concluímos disso que aquele que empresta dinheiro pertence, sim, à classe disponível, quanto à sua pessoa, porque não tem nada que fazer; mas não quanto à natureza de sua riqueza, sejam os juros de seu dinheiro pagos pelo proprietário das terras sobre uma porção de sua renda, sejam pagos por um empreendedor sobre a parte de seus lucros dedicada aos juros de seus investimentos.

\section{XCVII \\ Objeção.}

Dir-me-ão, sem dúvida, que o capitalista pode indiferentemente emprestar seu dinheiro ou empregá-lo em aquisição de terras; que, em um ou em outro caso, ele não retira senão um preço equivalente a seu dinheiro, e que, de qualquer maneira que o empregue, não deve contribuir menos para as despesas públicas.

\section{XCVIII}

Resposta à objeção.

Respondo primeiramente que, em verdade, quando o capitalista compra uma terra, o rendimento equivale para ele ao que teria retirado de seu dinheiro emprestando-o; mas há esta diferença essencial para o Estado: o valor que ele dá por essa terra em nada contribui para a renda que ela produz; ela não daria menor rendimento se ele a tivesse deixado de comprar: este rendimento é, como o explicamos, aquilo que a terra dá para além do soldo dos cultivadores, de seus lucros e dos juros sobre seus investimentos. Não se passa o mesmo com os juros de empréstimo: são a condição mesma do empréstimo, o preço do investimento, sem o qual o rendimento ou os lucros que servem para pagá-lo não existiriam.

Respondo, em segundo lugar, que, se unicamente as terras fossem incumbidas de contribuir para as despesas públicas, uma vez estabelecida essa contribuição, o capitalista que as comprasse não contaria, nos juros de seu dinheiro, a parte do rendimento dedicada a essa contribuição: assim como um homem que compra hoje uma terra não compra o dízimo que recebe o cura, mas o rendimento que resta uma vez feita a dedução desse dízimo.

\section{XCIX \\ Não existe rendimento verdadeiramente dispo- nível em um Estado além do produto líquido das terras.}

Vê-se, pelo que foi dito, que os juros sobre o dinheiro emprestado é tomado sobre o rendimento das terras ou sobre os lucros dos empreendimentos de cultura, de indústria ou de comércio. Mas esses lucros mesmos já demonstramos que são somente uma parte da produção das terras; que o produto das terras se divide em duas porções; que uma é dedicada aos soldos do cultivador, a seus lucros, a seu retorno e aos juros sobre seus investimentos; que a outra é a parte do proprietário, ou o rendimento que o proprietário gasta consigo e com o qual contribui para as despesas gerais do Estado. Demonstramos que tudo o que recebem as outras classes da sociedade não são senão soldos e lucros pagos, seja pelo proprietário sobre seu rendimento, seja pelos agentes da classe produtora sobre a parte dedicada a suas necessidades, que eles são obrigados a comprar da classe industriosa. Que os lucros sejam distribuídos nos soldos dos trabalhadores, nos lucros dos empreendedores, nos juros sobre investimentos, não os faz mudar de natureza, e não aumenta a soma do rendimento produzido pela classe produtora para além do preço de seu trabalho, soma da qual a classe industriosa não participa até ao pagamento do preço de seu trabalho.

Permanece constante, portanto, que não há rendimento além do produto líquido das terras e que qualquer outro lucro anual ou é pago pelo rendimento, ou faz parte dos custos que servem para produzir o rendimento. 


\section{C}

A terra também forneceu a totalidade das riquezas mobiliárias ou dos capitais existentes, os quais não são formados senão por uma porção poupada a cada ano de suas produções.

Não só não existe nem pode existir outro rendimento que o produto líquido das terras, mas é ainda a terra a que forneceu todos os capitais que formam a massa de todos os investimentos da cultura e do comércio. Ela ofereceu, sem cultura, os primeiros investimentos grandes e indispensáveis dos primeiros trabalhos; todo o restante é fruto acumulado da economia dos séculos que se sucederam desde que se começou a cultivar a terra. Essa economia se deu, sem dúvida, não só sobre o rendimento dos proprietários, mas ainda sobre os lucros de todos os membros das classes laboriosas. De maneira geral, é até verdadeiro que, ainda que os proprietários tenham mais excedentes, poupam menos, porque, tendo mais ócio, têm mais desejos, mais paixões; veem-se mais seguros com sua fortuna; pensam mais em frui-la agradavelmente do que em aumentá-la; o luxo é o que têm em comum. Os assalariados, e sobretudo os empreendedores das outras classes, recebendo os lucros proporcionalmente a seus investimentos, a seus talentos, a sua atividade, têm, ainda que não tenham rendimento propriamente dito, um excedente para além de sua subsistência; e quase todos, devotados a seus empreendimentos, ocupados em fazer crescer sua fortuna, afastados pelo trabalho dos divertimentos e das paixões dispendiosas, poupam seu excedente para vertê-lo em seus empreendimentos e aumentá-lo. A maioria dos empreendedores de cultura toma um pouco emprestado, e quase todos exploram apenas seus próprios fundos. Os empreendedores dos outros trabalhos, que querem tornar sólida sua fortuna, esforçam-se também por consegui-lo; e, a menos que tenham grande perícia, os que fazem seus empreendimentos sobre fundos de empréstimo arriscam-se muito a fracassar. Mas, ainda que os capitais se formem em parte pela economia dos lucros das classes laboriosas, como os lucros vêm sempre da terra, já que todos são pagos ou sobre o rendimento ou sobre os custos que servem para produzir o rendimento, é todavia evidente que os capitais vêm da terra assim como o rendimento, ou antes, que eles não são senão a acumulação da parte dos valores produzidos pela terra que os proprietários do rendimento, ou aqueles que com ele o partilham, podem poupar todos os anos, sem empregá-los em suas necessidades.

\section{CI}

Ainda que o dinheiro seja o objeto direto da economia, e que ele seja, por assim dizer, a matéria primeira dos capitais em sua formação, o dinheiro em espécie não forma senão parte quase insensível da soma total dos capitais.

Vimos que o dinheiro quase nada acrescenta à soma total dos capitais existentes; mas muito acrescenta na formação dos capitais. Com efeito, quase todas as poupanças só se fazem em dinheiro; é em dinheiro que os rendimentos retornam aos proprietários, que os investimentos e os lucros retornam aos empreendedores de todos os gêneros; é, portanto, dinheiro o que eles poupam, e o crescimento anual dos capitais se faz em dinheiro: mas todos os empreendedores não fazem dele outro uso que convertê-lo imediatamente em bens de diferentes naturezas sobre os quais se funda o empreendimento; assim, este dinheiro volta à circulação, e a maior parte dos capitais não existe senão em bens de naturezas diferentes, como já explicamos acima. cos 